\title{
Factors affecting semen preservation and conception rates in cattle
}

\author{
P. Shannon
}

\author{
New Zealand Dairy Board Animal Breeding Centre, Newstead R.D.4, Hamilton, New Zealand
}

The literature contains a bewildering number of reports on conception rates obtained in various artificial insemination (AI) programmes, but some of the confusion is caused by environmental differences and some by differences in methods of assessing fertility.

The present paper reviews the effect of the semen diluent, the method of semen storage, and the number of spermatozoa inseminated on fertility in AI programmes involving ambient-temperature semen, deep-frozen semen, and semen frozen in concentrated form, rediluted and used at ambient temperatures. Because a number of diluent components have been tested in more than one technique, these have been discussed together. Fertility results have been quoted as treatment differences because methods of fertility evaluation vary in different countries and give different absolute results (e.g. $65-66 \%$ for New Zealand and $78-79 \%$ for the U.K.). The differences in absolute results do not reflect efficiency of processing because semen processed in different countries gives the same results when used in a common environment (U.N., 1976).

\section{Fertility rates}

Any treatment applied to semen is likely to affect the fertilization rate. The probability that a spermatozoon will fertilize an egg depends upon at least one spermatozoon surviving at the site of fertilization until the ovum arrives, and this is dependent upon (1) insemination of enough spermatozoa, (2) the survival of the spermatozoa in the female tract and (3) the time of insemination in relation to ovulation. These three factors are not independent because deficiencies in one or two of them can be compensated for by excesses in the others.

\section{Sperm numbers}

To ensure the most sensitive comparison between two treatments it is necessary to arrange that fertility is well below optimum levels, i.e. $\left(1-q_{1}^{n_{1}}\right) \sim\left(1-q_{2}{ }^{n_{2}}\right) \bumpeq 1 \cdot 2$, where $\left(1-q_{1}\right)$ is the probability that a particular spermatozoon will fertilize the egg in treatment 1 ( $q_{1}=$ the probability of that spermatozoon not fertilizing the egg), $n_{1}=$ number of spermatozoa inseminated, and $q_{2}$ and $n_{2}$ are these factors in treatment 2. Manipulation of the treatment difference can be done by varying the dilution rate. For example, in New Zealand deep-frozen semen used at a dose rate of $25 \times 10^{6}$ spermatozoa has given results comparable with those from semen diluted in Caprogen and used at a dose rate of $2.5 \times 10^{6}$ spermatozoa. Reduction of the dose rate of deep-frozen semen to $12.5 \times 10^{6}$ spermatozoa reduced fertility by $6.5 \%$ to a level well below that achieved with the Caprogen-diluted semen (Macmillan, Shannon \& Hart, 1978).

The two most likely reasons for differences in the probability of fertilization are that the number of spermatozoa surviving a treatment are diminished, as in the case of deep-frozen semen, or that, although ultimate survival in the female tract is the same for two treatments, the pattern of decline in the female tract differs between treatments.

\section{Sperm survival}

Variation between sires can also cause differences in survival of spermatozoa in the female tract. In a comparison of sires of different fertility levels Macmillan \& Watson (1975) found that fertility of "above average" sires was unaffected by the stage of oestrus at time of insemination, but the per- 
formance of "below average" sires was affected. Whilst the overall difference between high- and lowfertility sires was $4.6 \%$ the difference was $15.9 \%$ for inseminations early in oestrus, $5.5 \%$ for inseminations in mid-late oestrus and zero for inseminations after oestrus.

Comparison of return intervals between the two groups of sires demonstrated that the differences in fertility were due to failure of fertilization. The results show that the sensitivity of specific fertility tests for survival can be greatly increased if the tests are conducted with cows at an early stage of oestrus. Conversely, the sensitivity of tests for capacitation will be increased if tests are conducted after oestrus when a higher proportion of cows will have ovulated or are close to ovulation.

\section{Insemination time}

The importance of survival of spermatozoa in the female tract can be deduced from the time of insemination relative to ovulation which occurs $30 \mathrm{~h}$ after the beginning of oestrus (Salisbury \& VanDemark, 1961). In New Zealand, cows first noticed in oestrus at the morning milking are inseminated the same morning, i.e. $\sim 6 \mathrm{~h}$ after first observation of oestrus, whilst cows first noticed in oestrus at the evening milking are inseminated the following morning, i.e. $\sim 18 \mathrm{~h}$ after observation of oestrus. The time of ovulation, relative to the time of insemination, for these two groups of cows is given in Table 1. As expected, more cows were inseminated after ovulation if oestrus was not seen until the evening milking and $>24 \mathrm{~h}$ before ovulation if oestrus was observed at the first milking. The overall pregnancy rate (determined by rectal palpation 120 days after insemination), $59 \cdot 5 \%$, was depressed by the lower conception rates in cows inseminated outside the period $0-24 \mathrm{~h}$ before ovulation. These results clearly show that their assessment relative to the time ovulation in the cows can determine the reason for fertility differences. For example, the precipitous decline in fertility with semen used about $50 \mathrm{~h}$ after collection compared to that with semen used about $26 \mathrm{~h}$ after collection was found to be partly due to the age of the semen and partly to the stage of oestrus at insemination (New Zealand Dairy Board, 1954). The difference in conception rate between the differently aged semen samples was $25 \%$ when cows were inseminated about $6 \mathrm{~h}$ after they were first noticed in oestrus, but only $8 \%$ when inseminated $30 \mathrm{~h}$ after being detected in oestrus. The difference in fertility with age of semen was clearly associated with survival in the female tract (interaction time of insemination $\times$ age of semen, $P<0.01$ ).

Table 1. The numbers of cows (as \% of total number of 346 ) inseminated at different times in relation to ovulation (from New Zealand Dairy Board, 1963)

\begin{tabular}{lccc}
\hline & \multicolumn{3}{c}{$\%$ cows inseminated } \\
\cline { 2 - 3 } & \multicolumn{2}{c}{ Before ovulation } \\
\cline { 2 - 3 } Observation of oestrus & $>24 \mathrm{~h}$ & $0-24 \mathrm{~h}$ & After ovulation \\
\hline Morning milking & 29 & 70 & 1 \\
Evening milking & 4 & 82 & 14 \\
Combined & $17(42 \cdot 1)$ & $76(65 \cdot 1)$ & $7(40 \cdot 3)$ \\
\hline
\end{tabular}

$\%$ of cows pregnant in parentheses.

\section{Dilution rate}

The objective of AI in cattle is the widespread use of superior sires and examination of effects on the dilution rate of semen is important.

Lowered conception rates due to dilution may not be a consequence of fewer spermatozoa but, in liquid semen, may reflect the adverse effect of high dilution on the survival of the spermatozoa (Shannon, 1965b). This adverse effect is related to $\mathrm{O}_{2}$ tension in the diluent. With air saturation the difference in survival at $37^{\circ} \mathrm{C}$ was $5.1 \mathrm{~h}$ in favour of storage for 2 days at $200 \times 10^{6} / \mathrm{ml}$ compared to storage at $12.5 \times 10^{6}$ spermatozoa/ml (both samples were incubated at $12.5 \times 10^{6}$ spermatozoa $/ \mathrm{ml}$ ). 
This difference increased to $14 \cdot 3 \mathrm{~h}$ after storage for 8 days. When the diluent was gassed with $\mathrm{N}_{2}$ the difference was 3.6 and $2.5 \mathrm{~h}$ respectively. The dilution effect can be simulated in samples stored at $300 \times 10^{6}$ spermatozoa $/ \mathrm{ml}$ by gassing the diluent with $\mathrm{O}_{2}$ (Shannon, 1965b). The difference between dilution rates can be further reduced by the addition of catalase (Macmillan, Tika \& Hart, 1972). In our experiments with Caprogen, gassing with $\mathrm{N}_{2}$ is routine.

Results of dilution rate trials with three commercially used techniques are of interest. Fertility of semen was maintained when it was stored at ambient temperature in Caprogen and the dose rate was reduced from $20 \times 10^{6}$ to $1.5 \times 10^{6}$ spermatozoa/insemination on the day after collection (Shannon, 1968; Milk Marketing Board, 1968b, 1969). Reduction of the dose rate to $0.5 \times 10^{6}$ resulted in a decline in fertility of approximately $7 \%$ (New Zealand Dairy Board, 1970, 1971, 1972). Reduction of the dose rate of semen deep frozen in straws from $20 \times 10^{6}$ to $10 \times 10^{6}$ spermatozoa/insemination reduced conception rates by $4.6 \%$ (Milk Marketing Board, 1971b). A further reduction to $6 \times 10^{6}$ total $\left(3 \times 10^{6}\right.$ motile $)$ and $0.75 \times 10^{6}$ total $\left(0.38 \times 10^{6}\right.$ motile $)$ spermatozoa reduced conception rates by 10 and $18 \%$ respectively (Jondet, 1974). With rediluted deep-frozen semen, the reduction in conception rate was $1.4 \%$ at $10 \times 10^{6}$ spermatozoa and $5.3 \%$ at $5 \times 10^{6}$ spermatozoa per insemination.

Reasons for the differences in dilution rate response are not known. That higher sperm numbers would be required with deep frozen semen, due to losses in the freezing process, is not unexpected. Nevertheless, the number of motile spermatozoa required to achieve optimum fertility is greater than that required with Caprogen. Assuming that the number of motile spermatozoa in frozen semen is $20 \%$, the number of motile spermatozoa required for fertility is $4 \times 10^{6}$. The effect must therefore be due not only to the reduction in the number, but also to the probability of conception by motile spermatozoa. That deep-frozen spermatozoa are more 'fragile' than fresh spermatozoa is demonstrated by the work of Desjardins \& Hafs (1962) in which the improvement in the fertility response to superior diluents was much greater with deep-frozen than with fresh spermatozoa. It is possible that the deep-freezing process may change patterns of survival in the female tract. Although deep-frozen semen gave essentially the same conception rates as liquid semen in New Zealand, the results, relative to the time of ovulation, differed. Conception rates with deep-frozen semen were slightly but not significantly higher with inseminations approximately $18 \mathrm{~h}$ after first observation of oestrus, but were significantly poorer with inseminations approximately $6 \mathrm{~h}$ after first detection of oestrus (Macmillan $\&$ Curnow, 1977). If the poor results at $6 \mathrm{~h}$ reflect a difference in the probability of conception because of a different pattern of decline of spermatozoa available for fertilization in the female tract, then the observed difference in the number of motile spermatozoa required for optimum results could be expected.

Results with rediluted deep-frozen semen are more curious. The decline with dilution is much less than with deep-frozen semen. The difference may be due to the initial freezing in a concentrated form or because the redilution medium confers some lasting benefit on the surviving spermatozoa. That the dilution medium has an important modifying effect on response to dose rate is evident from a trial with Caprogen in which catalase was replaced with EDTA. Both compounds protect spermatozoa from the effects of $\mathrm{H}_{2} \mathrm{O}_{2}$ but catalase is more effective in in-vitro and field fertility studies (Shannon \& Curson, 1972b; Shannon, 1973). Replacement of catalase with EDTA reduced conception rates by $2.6 \%$ at a dose rate of $2.5 \times 10^{6}$ spermatozoa/insemination, but this difference increased to $7.2 \%$ at a dose rate of $0.5 \times 10^{6}$ spermatozoa/ml (New Zealand Dairy Board, 1972).

Results with Caprogen show that the minimum number of spermatozoa required for optimum fertility is $1.5 \times 10^{6}$ total or $1 \times 10^{6}$ motile spermatozoa. The between-sire results with semen diluted in Caprogen (Macmillan \& Watson, 1975) are also of interest. Considerable differences exist between sires in fertilization rates after inseminations in early or late oestrus (see p. 520). If these differences reflect a difference in the probability of conception over a period of time, then a reduction in dose rate per insemination should substantially increase the difference between high- and low-fertility sires. Dilution rate trials with Caprogen have shown that a reduction from 5 to $1.5 \times 10^{6}$ spermatozoa/insemination had no adverse effect on low-fertility sires. It therefore appears that the change from an equal probability of conception for high- and low-fertility sires to high probabilities of conception for high-fertility and zero probabilities of conception for low-fertility sires occurs over a very short period with semen diluted in Caprogen. 


\section{Diluents}

Whilst considerable advances have been made in the biochemistry of semen, very little is known about factors which enhance survival and fertility. This lack of knowledge inhibits the rational formulation of diluents. Of the compounds discussed below (egg yolk, catalase, glycine, glycerol, caproic acid, and the capacitating enzymes $\alpha$ - and $\beta$-amylase and $\beta$-glucuronidase), we have reasonable knowledge of the effects, and therefore the ability to predict results, of only two, egg yolk and catalase.

Egg yolk. The discovery that egg yolk protected spermatozoa against cold shock (Philips, 1939) led to the commercial development of AI in cattle. Protective agents such as egg yolk are of value even when spermatozoa are not subject to cold shock because seminal plasma is known to have a detrimental effect on the survival of spermatozoa in diluted bovine semen (Shannon, 1965b, c, 1973; Bennett \& Dott, 1966; Dott, 1974). Seminal plasma acts on the cell membrane and causes an increased leakage of amino acid oxidase (Shannon, 1973).

The nature of the seminal plasma toxin(s) is imperfectly understood. Anti-sperm activity was found in all fractions derived from sequential acetone precipitation or column chromatography of seminal plasma (Shannon, Twomey \& Curson, 1974). The activity was non-dialysable at pH 7 in $0.9 \%$ $(\mathrm{w} / \mathrm{v}) \mathrm{NaCl}$ but was dialysable at $\mathrm{pH} \mathrm{3}$; if the $\mathrm{pH}$ of the dialysate was increased to $\mathrm{pH} 7$ the activity reverted to the non-dialysable form. At least part of the anti-sperm activity resides in a small molecular weight compound which normally exists as a polymer or bonded to other proteins.

Egg yolk protects spermatozoa from the seminal plasma (Shannon \& Curson, 1972a) by competing for sites on the cell membrane, and increasing the levels of seminal plasma can block completely the protective action of egg yolk against cold shock (Shannon, 1973). The hypothesis of the action of seminal plasma and the protective action of egg yolk is supported by the observation that egg-yolk lipoproteins become firmly attached to sperm membranes (Foulkes, 1977). The concentration of egg yolk required to protect the spermatozoa will thus depend on the semen dilution. In liquid semen stored at $5^{\circ} \mathrm{C}$ at a dilution of 1:50, the optimum concentration of egg yolk is 20-25\% (Salisbury \& VanDemark, 1961). At the higher dilution rates used for semen stored at ambient temperatures (approximately $1: 300$ ) much lower egg yolk proportions are effective: the $\%$ difference in conception rate was $+0.7 \pm 0.60$ for $5-20 \%$ egg yolk, $+1.0 \pm 0.38$ for $2-5 \%$ and $-1 \cdot 3 \pm 0.87$ for $1-2 \%$ egg yolk (P. Shannon, unpublished). However, even with an egg-yolk proportion of $1 \%$ some bulls maintained a better conception rate than others, perhaps because of different degrees of toxicity in their seminal plasma.

Catalase. Catalase protects spermatozoa against the deleterious effects of $\mathrm{H}_{2} \mathrm{O}_{2}$ (Macmillan et al., 1972 ) produced by the action of amino-acid oxidase on egg yolk (Tosic \& Walton, 1950), which is equivalent to a $0.1 \%$ solution of $\mathrm{L}$-phenylalanine (Shannon \& Curson, 1972b, 1978). The properties of amino-acid oxidase are well established : it is inactive in live spermatozoa, and it is heat-, acid- and alkali-labile, and depends on sulphydryl groups for activity (Shannon \& Curson, 1972b). Amino acid oxidase is probably the only toxic element in dead bovine spermatozoa because treatments which inactivate the enzyme, e.g. heat, ethyl maleimide, acid or alkali treatment, detoxify dead spermatozoa and only acetone fractions which exhibit oxidase activity have a toxic action on diluted spermatozoa. Activity at $15-20^{\circ} \mathrm{C}$ is 50 to 250 times the activity at $5^{\circ} \mathrm{C}$ (Shannon \& Curson, 1978).

From kinetic studies of the enzyme it would be expected that response would increase with increasing temperature and duration of storage. Not unexpectedly, the only significant response was with semen stored at ambient temperature. The $\%$ fertility difference was $-1.4 \pm 1.0$ for frozen semen (Foote, 1976), and $-0.7 \pm 0.4$ for chilled semen (Foote \& Dunn, 1962; Hafs, 1961 ; Shannon, 1973). The ambient temperature semen response was $+0.9 \pm 0.4$ for 6 -h-old semen and $+1 \cdot 7 \pm 0.3$ for 30 -h semen (Shannon, 1973).

Glycine. Glycine enhances the survival of diluted bovine semen stored at $5^{\circ} \mathrm{C}$ (Roy \& Bishop, 1954). Nevertheless, conflicting fertility results have been reported for glycine-containing diluents (Strom, 1956; Stower \& Bud Hasaim, 1957; Foote, Young \& Dunn, 1958; Salisbury \& VanDemark, 1961 ; Shannon, 1964). However, in many cases the incorporation of glycine into diluent was accompanied by other radical changes to the diluent, e.g. addition of glycerol (Stower \& Bud Hasaim, 1957) 
or reduction of egg-yolk level and bicarbonate addition (Foote et al., 1958), and these changes may have contributed to the fertility differences. A comparison of a $20 \%$ egg yolk $-2.9 \%$ citrate diluent with a $20 \%$ egg yolk $-2 \%$ citrate $-1 \%$ glycine $-0.3 \%$ glucose diluent gave a fertility advantage for the latter of $+2 \cdot 1 \pm 0.39 \%$ with semen used on the day of collection and $+2 \cdot 7 \pm 0 \cdot 56 \%$ with semen used on the day after collection. The advantage appears directly attributable to the incorporation of the glycine-glucose moiety (Shannon, 1964). Although the incorporation of glycine in certain circumstances has improved fertility in liquid semen, its incorporation into deep-frozen diluents has been detrimental (Sevinc \& Hafs, 1960; Martin, 1965).

Glycerol. In liquid semen diluents glycerol has been shown to reduce the decline in fertility associated with ageing semen, although in some cases fertility was depressed with semen used shortly after collection (O'Connor \& Smith, 1959; Almquist, 1962; Stewart, 1964a; Shannon, 1964). Shannon (1964) reported that the effect of glycerol may depend on the basic diluent to which it is added. A glycerol concentration of $1 \%$ increased conception rate when added to an egg yolk-citrate-glycineglucose diluent by $+1.4 \pm 0.63 \%$ with semen used on the day after collection but had no effect when added to CUE diluent $(-0.3 \pm 0.68 \%)$. Glycerol has also been reported to enhance the fertility of semen extended in Tris (Foote, 1970).

Caproic acid. Caproic acid enhances survival and fertility of diluted bovine semen (Shannon, 1962). In a large scale trial addition of caproic acid had no significant effect on fertility with semen used on the day of collection $(+0.4 \pm 0.54 \%$ ) but significantly increased the fertility of semen used on the day after collection $(+1 \cdot 3 \pm 0.54 \%$ ) (New Zealand Dairy Board, 1963). We have found no benefit from adding caproic acid to diluents for deep-freezing semen.

Capacitating enzymes. Although Mahajan \& Menge (1966) reported that capacitation of spermatozoa did not improve the fertilization rate of cows inseminated after ovulation, the use of enzymes to capacitate spermatozoa has been advocated. Results from the incorporation of the enzymes $\alpha$ - and $\beta$-amylase, $\beta$-glucuronidase and combinations of the enzymes have been variable (Kirton, Boyd \& Hafs, 1968; Hafs, Boyd, Cameron \& Dombroske, 1969; New Zealand Dairy Board, 1969, 1970; Hogan, Linford, Lawton, Stewart \& Westgarth, 1974; Foote, 1976). With deep-frozen semen Kirton et al. (1968) and Hogan et al. (1974) reported improved conception rates from the incorporation of the enzymes in diluents, but Bean (1976) and Foote (1976) found no benefit from inclusion of these enzymes.

In ambient-temperature semen the inclusion of $8 \mu \mathrm{g} \alpha$-amylase had no effect on fertility $(-0 \cdot 1 \pm$ 0.47\%) (New Zealand Dairy Board, 1969, 1970).

\section{Methods of semen storage}

\section{Ambient temperature}

In contrast to the IVT diluent (VanDemark \& Sharma, 1957) which was specifically designed for use at ambient temperatures, relying on metabolic inhibition by $\mathrm{CO}_{2}$ to enhance survival at elevated temperatures, Caprogen (Shannon, 1965b, 1968, 1973), which was developed as a diluent for use at $5^{\circ} \mathrm{C}$, proved superior for semen stored at temperatures of $15-27^{\circ} \mathrm{C}$. In field trials conception rates were increased by $0.9 \%$ for inseminations with semen collected that day and $2.2 \%$ for semen used the day after collection. The improved conception rates and the increase in the difference with age of semen indicate that in this diluent both cooling and storage at $5^{\circ} \mathrm{C}$ adversely affect the survival of spermatozoa. Caprogen used at ambient temperatures has been reported to give the same fertility results with $10 \times 10^{6}$ spermatozoa/insemination as does a milk diluent with $40 \times 10^{6}$ spermatozoa/insemination. There was no difference in conception rates with spermatozoa stored for up to 3 days in Caprogen (Milk Marketing Board, 1967, 1969).

\section{Deep freezing}

Early work on the development of techniques for deep-freezing semen since the first successful freezing of semen (Polge, Smith \& Parkes, 1949; Polge \& Rowson, 1952) have been reviewed by Mann 
(1964). Subsequent changes in the refrigeration media from solid $\mathrm{CO}_{2}$ at $-79^{\circ} \mathrm{C}$ toliquid $\mathrm{N}_{2}$ at $-196^{\circ} \mathrm{C}$, and the introduction of a more convenient packaging than ampoules, i.e. straws (Jondet, 1964; Cassou, 1967) and pellets (Perez, 1965), has led to some modifications of the original recommendations about freezing rate and equilibration. The change to lower storage temperatures has been reported to increase conception rates by $2-3 \%$ (Pickett, Martig \& Cowan, 1961; Stewart, 1964b; Josey, 1969). Equilibration for 6-8 h has been as effective as equilibration for $18-20 \mathrm{~h}$ (Jondet, 1967; Hunter, 1968; Milk Marketing Board, 1968a). Freezing rate is less critical than thawing rate (Robbins, Saacke \& Chandler, 1976), rapid thawing being superior to slow thawing (Aamdal \& Anderson, 1968; Milk Marketing Board, 1971b).

\section{Redilution of deep-frozen semen}

Several authors have reported on the freezing of spermatozoa in concentrated form with subsequent redilution and use as liquid semen (James \& Fyvie, 1955; Desjardins \& Hafs, 1962; Shannon, 1968, 1972; Macmillan et al., 1978). However, the results have been variable. James \& Fyvie (1965) found that rediluted material inseminated within $1 \mathrm{~h}$ of redilution gave good results but storage for 6 or $18 \mathrm{~h}$ resulted in a decline in conception rates of 12 and $45 \%$ respectively. Perez (1965) reported that survival of rediluted deep-frozen semen was very poor over a $24-\mathrm{h}$ period of storage. Desjardins \& Hafs (1962) made the important observation that the redilution medium was critical. Spermatozoa stored in CUE and rediluted had a $17 \%$ fertility advantage over storage in egg yolk-citrate, although the difference between diluents with fresh semen from the same bulls was only $2.4 \%$. The difference between rediluted semen and fresh semen in favour of fresh semen was $7.7 \%$ for semen diluted in CUE and $22 \%$ for semen rediluted in egg yolk-citrate.

The failure or partial failure of redilution techniques has in part been due to a lack of understanding of the toxicity of dead spermatozoa. Because of the large numbers of spermatozoa killed during freezing, $\mathrm{H}_{2} \mathrm{O}_{2}$ production becomes a problem even at low temperatures. At ambient temperatures the adverse effects are greater, but can be minimized by a reduction in $\mathrm{O}_{2}$ tension, an optimal egg-yolk level and the incorporation of catalase into the diluent. Freezing semen in $5 \mathrm{ml}$ aliquots in dialysis tubing, thawing and rediluting in Caprogen the following day at a dose rate of $2 \times 10^{7}$ spermatozoa $/ \mathrm{ml}$ gave results only $1.1 \%$ below those with fresh semen. Packaging of semen into straws, permitting more rapid thawing, has given slightly higher results.

\section{General considerations}

From the above it is apparent that when a treatment enhances or depresses survival or capacitation of spermatozoa but the change from equal probabilities of fertilization for the two treatments to zero for one treatment and high probabilities of fertilization for the other occurs over a short period of time, conception rate differences will exist between treatments at all dilution rates (e.g. between sire differences with semen diluted in Caprogen). If the effect is primarily on the probability of fertilization by a single spermatozoon, then the response will depend on dilution rate. Differences between treatments will disappear when they are compared at the optimum dilution rate for the inferior treatment (e.g. comparison between deep-frozen semen and semen diluted in Caprogen).

It is unfortunate that the most common form of experiment (which applies to all the diluent component experiments cited above), i.e. comparison with a currently used diluent at the optimum dilution rate for that diluent, will only detect fertility differences when the experimental diluent is inferior to the control diluent or significantly improves survival or capacitation of spermatozoa, i.e. both diluents should be tested with a range of dilution rates. While a large number of treatments and dilution experiments have demonstrated differences in fertility, it is impossible in many cases to derive the causes for these fertility differences. The classification of cows into groups according to the stage of oestrus and the use of heterospermic insemination techniques which measure fertility differences more sensitively (Beatty, Barnett, Hall, Hancock \& Stewart, 1969; Stewart, Spooner, Bennett, Beatty \& Hancock, 1974), may resolve whether differences between treatments are due to differences 
in survival, or the probability of conception by spermatozoa. The sensitivity of tests may also be increased by comparing treatments at high dilution rates. Fertility tests are, however, necessarily time consuming, and because of the potential risks to users fairly limited in scope, at least in the initial stages of technique examination. Laboratory tests which predict fertility reasonably accurately are therefore clearly desirable. Unfortunately, the relationship between laboratory tests and fertility is poor (Linford, Glover, Bishop \& Stewart, 1976). The lack of relationship is partly due to the high sampling variances of fertility. The value of such tests may be improved by using the appropriate statistical techniques to remove the confounding effect of binomial variation and uncover the true biological relationship between the test and fertility (Shannon \& Searle, 1962; Shannon, 1965a; Van Duijn, 1964a, b). The New Zealand results show that sperm survival in the female tract is important. If tests fail to indicate this they may be poor predictors of fertility. Ideally a survival test should be included in the testing procedure. Such a test should measure not only ultimate survival but the pattern of decline. There are pitfalls, of course. For example, the incubation life of deep-frozen semen may simply reflect the number of dead spermatozoa because the production of $\mathrm{H}_{2} \mathrm{O}_{2}$ will be directly related to that number (Shannon \& Curson, 1972a). Moreover, such tests are mainly subjective and it is difficult to estimate consistently the percentage of dead spermatozoa and changes in motility that occur with incubation time. The development of equipment such as the Quantimet (Dott, 1975; Katz \& Dott, 1975) and the application of laser technology (Harvey et al., 1978) promises more critical methods of evaluation.

\section{References}

Aamdal, J. Anderson, K. (1968) Fast thawing of bull semen frozen in straws. Proc. 6th Int. Congr. Anim. Reprod. \& A.I., Paris, Summaries, p. 154.

AlmQuist, J.O. (1962) Diluents for bovine sperm. XI. Effect of glycerol on fertility and motility of spermatozoa on homogenised milk and skim milk. J. Dairy Sci. 45, 911-916.

BEAN, B.H. (1976) Unpublished results quoted by Foote, R. H. (1976).

Beatty, R.A., Barnett, G.H., Hall, J.G., Hancock, J.L. \& StewarT, D.L. (1969) An experiment with heterospermic insemination in cattle. J. Reprod. Fert. 19, 491-502.

BenNetT, J.P. \& DotT, H.M. (1966) An effect of bovine seminal plasma on the impedance change frequency of epididymal spermatozoa collected from the living bull. J. Reprod. Fert. 12, 327-336.

Cassou, R. (1967) Medium sized straws at L'Aigle A.I. Centre. Elevage Insem. 97, 3-9. [Anim. Br. Abstr. 35, p. 2472, (1967).]

Desuardins, C. \& Hafs, H.D. (1962) Motility and fertility during post-thawing storage of bovine sperm concentrated, thawed and re-extended. J. Dairy Sci. 45, 1242-1247.

DotT, H.M. (1974) The effect of bovine seminal plasma on the impedance change frequency and glycolysis of bovine epididymal spermatozoa. $J$. Reprod. Fert. 38, $147-156$.

DotT, H.M. (1975) The estimation of the proportion of motile bull spermatozoa in various diluents and a comparison with the proportion eosinophilic. $J$. Reprod. Fert. 45, 47-55.

Foote, R.H. (1970) Fertility of bull semen at high extension rates in Tris buffered extenders. J. Dairy Sci. 53, 1475-1477.
Foote, R.H. (1976) Fertility of bull semen frozen with $\beta$-amylase, $\beta$-glucuronidase and catalase. J. Dairy Sci. 59, 2014-2017.

FoOTE, R.H. \& DUNN, H.O. (1962) Motility and fertility of bull semen extended at high rates in yolk extender containing catalase. J. Dairy Sci. 45, 1237-1241.

Foote, R.H., Young, D.C. \& DunN, H.O. (1958) Fertility of bull semen stored for one or two days at $5^{\circ} \mathrm{C}$ in 20 per cent glycine glucose extenders. $J$. Dairy Sci. 41, 732-734.

FouLKES, J.A. (1977) The separation of lipoproteins from egg yolk and their effect on the motility and integrity of bovine spermatozoa. J. Reprod. Fert. 49, 277-284.

HaFs, H.D. (1961) Fertility of bull sperm with added catalase. J. Dairy Sci. 44, 1529-1536.

Hafs, H.D., Boyd, L.J., Cameron, S. \& Dombroske, F. (1969) Fertility of bull semen with amylase and Polymixin. A.I. Digest 17, 8-9.

Harvey, J.D., Walls, D.F., Woolford, M.W., Woolhouse, J.R., Shannon, P. \& Curson, B. (1978) Determinations of live dead fractions of bovine spermatozoa by laser light beating spectroscopy. N.Z. Jl exp. Agric. (in press).

Hogan, C.O., Linford, E., Lawton, F., Stewart, D.L. \& Westgarth, D.R. (1974) The influence of $\beta$ amylase and $\beta$-glucuronidase on the fertility of frozen semen. Br. vet. J. 130, 292-298.

HUNTER, K.W. (1968) Glycerolisation and freezing techniques with bull semen. Proc. 6th Int. Congr. Anim. Reprod. \& A.I., Paris, Summaries, p. 172.

JAmES, J.P. \& FyviE, A.A. (1955) Techniques and results of low temperature bull semen storage. N. Z. Soc. Anim. Prod. 15, 126-131.

JoNDET, R. (1964) The rapid freezing of bull semen conditioned in straws. Proc. 5th Int. Congr. Anim. Reprodo \& A.I., Trento 4, 463-468. 
JONDET, R. (1967) Influence of equilibration time on freezing and fertilising capacity of bull semen. $C . r$. hebd. Séanc. Acad. Agric. Fr. 53, 1407-1412. [Anim. Br. Abstr. 37, p. 2513 (1969).]

JoNDET, R. (1974) Transport des spermatazoides chez la vache et fertilitie apres inseminations artificielle avec les nombres reduit de spermatozoides. Editions Inserm, pp. 357-388.

JoSEY, M.J. (1969) Motility and fertility of bovine semen stored at $-79^{\circ} \mathrm{C}$ and $-196^{\circ} \mathrm{C}$. Qd agric. J. 26, 651657.

KATZ, D.F. \& DotT, H.M. (1975) Methods of measuring swimming speed of spermatozoa. J. Reprod. Fert. 45, 263-272.

KIRTon, H.D., Boyd, L.J. \& Hafs, H.D. (1968) Fertility of bull semen with added amylase. J. Dairy Sci. 51, 1426-1428.

Linford, E., Glover, F.A., Bishop, C. \& Stewart, D.C. (1976) The relationship between semen evaluation methods and fertility in the bull. J. Reprod. Fert. 47, 283-291.

Macmillan, K.L. \& Curnow, R.J. (1977) Factors influencing $A B$ conception rates. $X$. Seasonal trends in fertility and in the distribution of return intervals. Difference between deep frozen and liquid semen. N. Z. Jl exp. Agric. 5, 273-278.

Macmillan, K.L. \& Watson, J.D. (1975) Fertility differences between groups of sires relative to the stage of oestrus at the time of insemination. Anim. Prod. 21, 243-249.

Macmillan, K.L., Tika, J.L. \& Hart, N.L. (1972) Toxic effects of aromatic amino acids and the livability of bull spermatozoa. Aust. Jl biol. Sci. 25, 1039-1045.

Macmillan, K.L., Shannon, P. \& Hart, N.L. (1978) The redilution of deep frozen semen. Anim. Prod. 26, 67-73.

Mahajan, S.C. \& Menge, A.C. (1966) Influence of uterine environment of the fertilising capacity of sperm in cattle. J. Anim. Sci. 25, 1083-1086.

MANN, T. (1964) The Biochemistry of Semen and of the Male Reproductive Tract, pp. 359-363. Methuen, London.

MarTIN, I.C.A. (1965) Effects of cooling to $5^{\circ} \mathrm{C}$, storage at $5^{\circ} \mathrm{C}$, glycerol concentration, sodium chloride, fructose and glycine on the revival of deep frozen spermatozoa. J. agric. Sci., Camb. 64, 425-432.

Milk Marketing Board (1967) Trials with caprogen. Report of the Breeding and Production Organisation 17, 64-65.

Milk Marketing Board (1968a) Milk diluents. Report of the Breeding and Production Organisation 18, 132134.

Milk Marketing Board (1968b) The use of caprogen and catalase in the field. Report of the Breeding and Production Organisation 18, 128-129.

Milk Marketing Board (1969) Caprogen-diluted semen in pipettes and straws. Report of the Breeding and Production Organisation 18, 145-148.

Milk Marketing Board (1971a) The fertility of semen frozen in quarter cc straws using four dose rates. Report of the Breeding and Production Organisation 21, 100-101.
Milk Marketing Board (1971b) One day trial to test the effect of thawing temperature. Report of the Breeding and Production Organisation 18, 128-129.

New Zealand DaIRY Board (1954) Conception rate according to age of semen and stage of heat. Annual Report 31, 69-70.

New Zealand Dairy Board (1963) Research into semen diluents and methods of storage. Annual Report 39, 52-53.

New Zealand Dairy Board (1969) Current research. Annual Farm Production Report 45, 31.

New Zealand DaIRY Board (1970) Semen studies Annual Farm Production Report 46, 16-17.

New Zealand DaIRY Board (1971) Semen studies. Annual Farm Production Report 47, 16-17.

New Zealand Dairy Board (1972) Semen studies. Annual Farm Production Report 48, 20-21.

O'CoNNOR, L.K. \& SMITH, G.E. (1959) The comparative fertility of bovine semen of four ages, diluted with skim milk and skim milk plus glycerol. J. agric. Sci., Camb. 53, 354-357.

Perez, M. (1965) New method of preserving semen by freezing. (1) Freezing in the concentrated form and redilution for preserving $24-48$ hours at $5^{\circ} \mathrm{C}$. (2) Freezing of concentrated semen, redilution at time of use. Élevage Insem. 88, 3-8. [Anim. Breed. Abstr. (1966) 34, 210 (No. 1210)].

Philips, P.H. (1939) The preservation of bull semen. $J$. biol. Chem. 130, 415.

Pickett, B.W., Martig, R.C. \& Cowan, W.A. (1961) Preservation of bovine spermatozoa at $-79^{\circ} \mathrm{C}$ and -196 ${ }^{\circ}$ C. J. Dairy Sci. 44, 2089-2096.

Polge, C. \& Rowson, L.E.A. (1952) Results with bull semen stored at $-79^{\circ} \mathrm{C}$. Vet. Rec. 64, 851-853.

Polge, C., Smith, A.U. \& Parkes, A.S. (1949) Revival of spermatozoa after vitrification and dehydration at low temperatures. Nature, Lond. 164, 166.

Robbins, R.K., SAaCke, R.G. \& Chandler, P.T. (1976) Influence of freeze rate, thaw rate and glycerol level on acrosomal retention and survival of bovine spermatozoa frozen in french straws. J. Anim. Sci. 42, 145-154.

RoY, A. \& Bishop, M.H.W. (1954) Effect of glycine on the survival of bull spermatozoa in vitro. Nature, Lond. 174, 746-747.

Salisbury, G.W. \& VANDEmaRK, N.L. (1961) Physiology of Reproduction and Artificial Insemination of Cattle, pp. 415-425. W. H. Freeman and Co., San Francisco.

SEvinc, M.H. \& HAFS, H.D. (1960) The effects of various diluents on freezing bull semen and re-extending it after thawing. Ankara Univ. vet. Fak. Derg. 7, 79-93.

ShanNON, P. (1962) Effect of additions of volatile fatty acids on the viability and fertility of diluted bovine semen. Nature, Lond. 196, 1225-1226.

Shannon, P. (1964) The effect of diluents containing glycine and glycine and glycerol on the fertility of diluted bovine semen. N. Z. Jl agric. Res. 7, 357-363.

SHANNON,P. (1965a) Contribution of binomial variation, technician, herds, and cows to observations of between cow variation of conception rates. J. Dairy Sci. 48, 85-89.

ShanNON, P. (1965b) Contribution of seminal plasma, sperm numbers, and gas phase to dilution effects of bovine spermatozoa. J. Dairy Sci. 48, 1357-1361. 
Shannon, P. (1965c) Presence of a heat-labile toxic protein in bovine seminal plasma. J. Dairy Sci. 48, $1362-1365$.

Shannon, P. (1968) Advances in semen dilution. N. $Z$. Soc. Anim. Prod. 28, 23-31.

Shannon, P. (1972) The diotube method of freezing semen for use as rediluted deep freeze. Proc. $7 \mathrm{th}$ Int. Congr. Anim. Reprod. \& A.I., Munich 4, 1363-1367.

Shannon, P. (1973) Factors affecting storage of semen. N. Z. Soc. Anim. Prod. 33, 40-48.

ShanNon, P. \& CuRson, B. (1972a) The effect of egg yolk levels on bovine seminal plasma toxins. Proc. $7 \mathrm{th}$ Int. Congr. Anim. Reprod. \& A.I., Munich 4, 1360-1362.

Shannon, P. \& Curson, B. (1972b) Toxic effect and mode of action of dead sperm on diluted bovine semen. J. Dairy Sci. 55, 614-620.

Shannon, P. \& Curson, B. (1978) Kinetics of bovine L-amino acid oxidase. $N$. $Z$. Il exp. Agric. (in press).

Shannon, P. \& Searle, S.R. (1972) Heritability and repeatability of conception rates of bulls in artificial breeding. J. Dairy Sci. 45, 86-90.

Shannon, P., Twomey, A. \& Curson, B. (1974) Antibacterial and anti sperm effect of seminal plasma. N. Z. Soc. Anim. Prod. 34, 61-64.

STEWART, D.L. (1964a) The effect on fertility of the addition of glycerol to skim milk egg yolk diluents. Proc. 5th Int. Congr. Anim Reprod. \& A.I., Trento 4, 631-635.

STEWART, D.L. (1964b) Observations on the fertility of frozen semen stored at $-79^{\circ} \mathrm{C}$. Proc. 5th Int.
Congr. Anim. Reprod. \& A.I., Trento 4, 617-623.

Stewart, D.L, SPooner, R.L., Bennett, G.H, Beatty, R.A. \& Hancock, J.L. (1974) A second experiment with heterospermic insemination in cattle. J. Reprod. Fert. 36, 107-116.

Stower, J. \& Bud Hasaim, P. (1957) Conception rates with bull semen diluted in glycerolised egg yolk fructose diluent. J.agric. Sci., Camb. 49, 220-222.

Sтrom, S. (1956) Comparison of the effects of egg yolk citrate and egg yolk glycine diluents on the fertilising ability of bovine semen. Proc. 3rd Int. Congr. Anim. Reprod. \& A.I., Cambridge 3, 71-72.

Tosic, J. \& Walton, A. (1950) Metabolism of spermatozoa. The formation and elimination of hydrogen peroxide by spermatozoa and effects on motility and survival. Biochem. J. 47, 199-212.

UNITEd Nations (1977) Testing of different strains of Friesian cattle in Poland. Institute of Zootechnics. Cracow 3rd Annual Report.

VanDemark, N.L. \& Sharma, U.D. (1957) Preliminary fertility results from the preservation of bovine semen at room temperature. J. Dairy Sci. 40, 438-439.

VAN DUIJN, C. (1964a) Parameters of spermatozoan movement in relation to season of bulls in the Netherlands. Proc. 5th Int. Congr. Anim. Reprod., Trento IV, pp. 307-321.

VAN DuIn, C. (1964b) Kinetics of fertility of semen. Proc. 5th Int. Congr. Anim. Reprod., Trento IV, pp. 313-322. 